\title{
The Predictors of Employment Generation in Informal Businesses in Calabar Metropolis, Cross River State, Nigeria
}

\author{
Eboh, Samuel Chukwuma ${ }^{1}$ Ibiang, Eno Itobo ${ }^{2}$ Ofem, Ubi Eni ${ }^{3}$ \\ 1.Dept of Economics, CRS College of Education, Akamkpa, Cross River State, Nigeria \\ 2.Dept of Geography, CRS College of Education, Akamkpa, Cross River State, Nigeria \\ 3.Dept of Business Education, CRS College of Education, Akamkpa, Cross River State
}

\section{Acknowledgement:}

This research is sponsored by Tertiary Education Trust Fund (TETFUND), Nigeria.

\begin{abstract}
The purpose of the study is to identify the predictors of employment generation in informal businesses in an urban setting. The methodology adopted for the study was a cross-sectional research approach. The population of the study is all informal businesses in Calabar. The respondents were informal business owner in the study. Stratified random sampling technique was used in selecting the businesses used in the study. A sample size of 252 businesses representing $15 \%$ of all registered businesses was used for the study. A structured questionnaire was used in collecting the data. The collected data was analysized using simple percentages and analysis of variance (ANOVA). The result showed a significant variation in employment generation among informal businesses. The predictors of employment generation among the informal businesses were identified as; type of business, income generation, size of business and quality of services. It is therefore concluded that a positive change in the characteristics of businesses will lead to increase in employment generation.
\end{abstract}

Keywords: Informal business, Employment generation \&Predictors of Employment generation.

DOI: $10.7176 /$ RHSS/10-18-08

Publication date:September $30^{\text {th }} 2020$

\section{Introduction}

Unemployment rates are rising everyday in the cities of the developing countries despite many decades of accelerated industrialization. Cities in the developed worlds are centres of industrialization and trade thus providing job opportunities for people. The roles cities play in the economic development of the countries have often attracted influx of rural migrants thus resulting in increased labour force. The rural migrants storm the cities in search of better living conditions, jobs and higher income. This has given rise to high rate of unemployment. The rising unemployment stems from the inability of the industrial sector to generate employment opportunities to cope with the ever increasing urban population. More so, the industrial sector requires specialized skills which unfortunately most rural migrants do not possess. Rural migrants without skills therefore often find it difficult to gain employment in the cities and thus remain unemployed.

Following the growing awareness of the deteriorating employment situations in cities, the International Labour Organisation (ILO) initiated a World Employment Programme in 1969 and the aim was focused on employment creation by the informal sector. The programme provided alternative strategy for employment creation. The adoption of the International Labour Organisation strategies toward job creation therefore created more employment opportunities in the cities. This initiative, encouraged many countries to embark on skill acquisition programmes tailored towards equipping the participants with skills for employment in the informal sector of the economy.

The informal sector has therefore being an alternative strategy for closing the yearning gap in employment generation. The important role played by the informal sector, the knowledge about the employment generative capacity and the factors affecting employment generation of the informal businesses is not well understood. It is from this perspective that a study on employment generation by informal businesses in Calabar urban is being undertaken.

\subsection{Problem of the Study}

Unemployment rates are increasing everyday in urban areas of Nigeria. Rapid industrialization has recent times failed to absolve the urban labour force in Nigeria. In the face of increasing unemployment, rural dwellers still troop into the cities in search of employment and better living conditions. Unfortunately in Nigeria, the agricultural sector that was providing about $70 \%$ employment has been on the decline. Even the industrial sector that was the second employer of labour has limited capacity to employ all the teeming population.

The informal businesses have recently become the alternative strategy for generating more employment opportunities. Such strategy has been through skills acquisition programmes, aimed at equipping participants with skills to start their own businesses and become employers of labour. 
Today, we have so many small scale businesses which are generating employment. It is generally argued that the small business are generating more employment than the formal sector, it is however not known the main predictors of employment generation in the small scale businesses in urban centres. It is therefore imperative to identify the predictors of employment generation among the informal businesses to guide policy formulation. The aim of this study is therefore to identify the predictors of employment generation among informal businesses in the study area.

\subsection{Purpose of the Study}

The purpose of the study is to identify the variables predicting employment generation among small scale businesses in Calabar urban, Cross River State, Nigeria.

The objectives of the study are as follows;

i) To examine the variation in employment generation among the small scale businesses in study area.

ii) To identify the predictors of employment generation by the small scale businesses in the study area.

\subsection{Research Questions \& Hypothesis}

The research questions for the study were:

i) Is there any variation in employment generation among the small scale businesses in the study area?

ii) What are the factors affecting employment generation among the small scale businesses?

In view of these research questions, two hypotheses were formulated and stated as follows:

1) There is no significant variation in employment generation among the small scale businesses in the study area.

2) Employment generation by small scale businesses is not predicted by any variable.

This study is significant because the rising unemployment rate in Nigeria requires that more researches be conducted on employment creation for the ever growing urban labour force. Studies that would identify the employment potential of formal and informal businesses would guide policy formulation on employment creation. It will also stimulate comparative studies in job creation. The study, in addition will provide a frame work for government interventions on employment creation by small scale businesses. Finally, it will boast further research in employment generation by informal businesses.

The scope of the study is limited to small scale businesses in Calabar city. The study therefore focused on small scale businesses classified as service, manufacturing, processing, agro-based, light engineering and construction businesses in the study area. The study covered 252 businesses cutting accross all classes of small scale businesses.

The study area is Calabar city, the capital of Cross River State. Calabar city is presently made up of Calabar Municipality and Calabar South Local Government Areas. It is located between Latitude $4^{0} 51^{1}$ and $5^{0} 04^{1} \mathrm{~N}$, Longitude $8^{0} 18^{1}$ and $8^{0} 24^{1} \mathrm{E}$. It covers an approximate area of 137.039 square kilometers (sq $\left.\mathrm{km}\right)$. It is about $98 \mathrm{~m}$ above sea level. It has a population of about 461,796 people (NPC, 2006) and a projected population of 529,362 in 2015 it is a major urban centre in the state thus performing administrative, socio-economic and commercial functions.

The city being the state capital as well as a major economic and commercial centre, attracts rural dwellers from within and outside the state. The influx of people to the city creates unemployment problems, thus, making it imperative to explore ways of creating more employment opportunities.

A survey conducted by the State Ministry of Commerce and Industries in 2004 reported that Calabar city had over 983 number of registered small scale businesses which provided employment opportunities to the youths. The number of small businesses must have increased overtime, especially with the state government emphasis on small scale business development. This small businesses have been providing employment opportunities to the residents of Calabar, but the proportion of employment creation by each of the businesses may nto be known.

\section{Concept of Informal Business}

Informal business is referred to as private sector by Ndebbio (1987). Oshagbemi (1983) and Adedokun (1987) called it Small Scale business or micro businesses. They all refer to the same concept. Akintoye (2008) therefore defined small scale business as a business with low employee, low scale volume and small capital. Omotosho (2015) rather described it as all businesses that are not public or government owned. Onokerhoraye (1996) and Ofoegbu (2010) using organizational structure defined informal business as an unregistered commercial enterprise that has no formal organizational structure. Oluseye, Ikhide and Akoytey (2017) in adopting the above definition stated that it is a one-man business outfit with machinery and equipment not exceeding N150,000 with major reliance on the use of local resources and is labour intensive, providing goods and services to the population. To introduce another dimension into the definition, Ndem, Effiong and Obot (2018) argued that small scale business is a self employed business with or without employees. To give a qualitative definition, the Federal Ministry of Industries in 1990 provided a more precised definition of small scale business as a business concern employing 
between 1 to 50 people. This definition used only one variable (number of employees) in describing informal business.

In another dimension, the Nigerian $3^{\text {rd }}$ National Development Plan, 1972, using the employee and investment variables stated that a small scale is a business concern with less than 10 employees whose investment in machinery and equipment do not exceed N600,000.

All the definitions so far reviewed highlighted the characteristics of a small scale business to include, employees' size, investment size and annual turn-over size. International Labour Organisation (ILO) in contributing to the debate stated that small scale business is an enterprises characterized with ease of entry, reliance on indigenous skills, family ownership, small scale operation, labour-intensive and utilization of skills acquired mainly outside the formal education system. This seems to be a more comprehensive definition and will be adopted in this study.

The above definitions point to the fact that small scale businesses are varied in nature and the classification of the businesses is necessary. Akintoye (2008) classified informal businesses into four; as follows; primary informal business that is agricultural, hunting, logging, mining, livestock and fisheries. This type of small scale businesses are recently on the decline especially in the urban centres (Ofogbu, 2010). The second category is secondary small scale businesses which include traditional craft such as blacksmithing, carving, weaving, woodwork, welding, shoe-making among others. Other categories are the distributive businesses and the tertiary small scale businesses such as transport operators, restaurants, hair dressing, laundering, photography and others.

Omolayole (1984), Oshagbemi (1983) and Obeleogu-Nelibe (1990) classified small scale business as agroallied, manufacturing, light engineering and construction, commercial services and finance and investment. This classification is relevant in the contemporary time, hence, it is adopted in this study.

Employment generation is the ability of an enterprise to create or provide employment to a number of people at a particular time (ILO, 1969). The aggregate number of people employed by the informal sector is said to be high especially in Nigeria. The enterprise baseline survey of small and medium scale enterprises of 2012 revealed that there are about 17 million small and medium scale enterprises employing 32-41million people. Ndem, et al (2018) further acknowledged that small scale businesses are the major source of employment generation in Nigeria. This is because most of the formal businesses have already reached their optimum level of employment which if exceeded profit cannot be maximized. Omotosho (2015) and Onyemaechi (2013) stated that the declining agricultural base of Nigeria tend to worsen the employment generation of the formal sector. Similarly, Callaway (1969) and Onyemaechi (2013) argued that the manufacturing industries have not been creating enough employment opportunities to cope with the rapid growing urban labour force in recent time.

The failure of the agricultural and industrial sectors to generate adequate employment opportunities call for the formulation of alternative strategies toward employment generation in Nigeria. omotosho (2015) and Valle (2012) in investigating employment generation by small scale businesses in Nigeria concluded that the small scale businesses have higher employment generative capacity than the informal businesses. To buttress the above, Oluseye, Ikhide and Akotey (2017) argued that small scale businesses have the capacity of creating jobs for skilled and unskilled manpower unlike the formal business. Oluseye, et al (2017) in aligning with the above, stated that the informal businesses have wider range of activities and job schedules that demand a larger number of people than the formal businesses.

The shortcoming of the cited studies is that they have not identified the employment generative capacity of the respective small scale businesses. Oluseye et al (2017), for instance, merely highlighted that informal service businesses provided about $57 \%$ employment, hotel and catering $8 \%$; retailing $15 \%$, transport service $10 \%$, building and construction $7 \%$ and manufacturing $3 \%$, but did not state the employment generation of each of the businesses.

These findings collaborates Onokerhoraye's (1986) study of informal businesses in Ilorin where the tertiary informal businesses accounted for a total of 20,329 employments out of 34,758 in the three sectors. In this area, the tertiary small scale business, trade/commerce, transport and manufacturing accounted for 15,258, 3,129 and 1, 121 , respectively. The conclusion is that the tertiary informal businesses generated more employment than other sectors in the study.

The reviewed studies have highlighted the employment generation of the informal businesses but have highlighted the variables affecting employment creation by the businesses in the study area. This study is therefore designed to bridge this noticeable gap by identifying the predictors of employment generation in informal businesses.

\section{Research Methodology}

A field survey methodology approach was adopted in the study. The approach provided the opportunity for collection of representative samples of the variables under investigation.

Data for the study was collected using a structured questionnaire designed to elicit responses on type of small scale businesses, employees, sources of funding, daily income, machines and equipment, local resource utilization, products, marketing strategies, business ownership and challenges facing the businesses. 
All informal businesses in Calabar urban constituted the study population. Sample size of 252 small scale businesses was used for the study. Stratified random sampling technique was adopted in selecting the businesses. The study area was divided into ten zones and ten businesses were randomly selected from each zone. The sample frame used in selecting the businesses was the list of businesses compiled during the reconnaissance survey.

Data collected from the field was organized into tables using percentages and other qualitative techniques. To test the formulated hypotheses, analysis of variance was used. The null hypothesis would be rejected if the calculated F-value is greater than the critical value at 0.05 level of significance. The multiple regression stepwise model was used in identifying the variables predicting employment generation among the small scale businesses.

The variables under consideration were; type of small scale business, source of income, average daily income, number of employees, type of services rendered and number of business units. These variables are termed independent variables while employment generation is the dependent variable.

\section{Results}

The result of the study showed the general characteristics of informal businesses in the study area as presented below;

Table 1: Types of Business Ownership in the Study Area

\begin{tabular}{|l|l|c|c|}
\hline S/N & Business Ownership & No. of Businesses & Percentage of Business Ownership \\
\hline 1 & Sole proprietorship & 197 & 78 \\
\hline 2 & Family ownership & 42 & 17 \\
\hline 3 & Joint ownership & 13 & 5 \\
\hline & Total & $\mathbf{2 5 2}$ & $\mathbf{1 0 0}$ \\
\hline
\end{tabular}

Table 1 showed that informal businesses in the study area are majorly owned by sole proprietors. The sole proprietors own about $78 \%$ of the businesses. Only $5 \%$ of the businesses are jointly owned. The ownership of informal businesses is likely to affect employment generation in the study area.

The source of financing the informal businesses is another attribute of the informal businesses in the study area. Table 2 highlights the sources of financing the businesses.

Table 2: Sources of Financing Informal Businesses

\begin{tabular}{|c|c|c|c|}
\hline $\mathbf{S} / \mathbf{N}$ & Sources of Financing & No. of Businesses & Percentage of Financing \\
\hline 1 & Personal saving & 174 & 69 \\
\hline 2 & Family savings & 50 & 19 \\
\hline 3 & Joint financing & 19 & 8 \\
\hline 4 & Loans/grants & 9 & 4 \\
\hline & Total & 252 & 100 \\
\hline
\end{tabular}

This result reveals that $69 \%$ of the businesses are financed through personal savings, while $19 \%$ are financed by family members through family savings. Only $4 \%$ of the businesses are financed through loans and grants from financial institutions. This may explain the limited size of small scale businesses in the study area. The average daily income of the informal businesses is as presented in Table 3 .

Table 3: Average Daily income of Informal Businesses

\begin{tabular}{|c|c|c|c|}
\hline $\mathbf{S} / \mathbf{N}$ & Average Daily Income (\#) & No. of Businesses & Percentage of Daily Income \\
\hline 1 & Less than 2,000 & 157 & 62 \\
\hline 2 & $2,000-5,000$ & 80 & 32 \\
\hline 3 & $6,000-10,000$ & 10 & 4 \\
\hline 4 & Above 10,000 & 5 & 2 \\
\hline & Total & 252 & 100 \\
\hline
\end{tabular}

Table 3 shows that $62 \%$ of informal businesses generated average daily income of less than N2,000, while $32 \%$ generated daily income of between N2,000 and N5,000. Only $6 \%$ of the businesses generate average daily income of above N6,000. The income generation by the informal businesses in the study area is very low. This may affect employment generation by the businesses.

Type of employment provided in the informal businesses is another characteristic of informal businesses. This is used in identifying one form of informal businesses from the other. Table 4 shows the type of employment needed in the informal businesses. 
Table 4: Type of Employment in Informal Businesses

\begin{tabular}{|l|l|c|c|}
\hline S/N & Type of Employment & No. of Businesses & Percentage of Employment \\
\hline 1 & Manager & 28 & 11 \\
\hline 2 & Journey men (Technicians) & 47 & 19 \\
\hline 3 & Sales personnel & 23 & 9 \\
\hline 4 & Cashiers $\quad$ Total & 37 & 15 \\
\hline 5 & Security men $\quad 67$ & 27 \\
\hline & & $\mathbf{2 5 2}$ & $\mathbf{1 0 0}$ \\
\hline
\end{tabular}

Table 4 shows that only $11 \%$ of the informal businesses employed managers to manage the businesses, while $19 \%$ employed journey men (Technicians). In addition, 9\%, 15\%, 27\% and 19\% were employed as sales personnel, cashiers, security-men and cleaners respectively by the businesses. This result implies that the informal businesses in the study area employ more of unskilled labour. This reveals the nature of employment that small scale businesses can generate.

To ascertain the variation in employment generation, null hypothesis which stated that, there is no significant variation in employment generation among small scale businesses in the study area. One-way Analysis of Variance (ANOVA) was used in testing the hypothesis. The result is as presented in table 5.

Table 5: One-way Analysis of Variance (ANOVA) of Informal Businesses and Employment Generation in the Study Area

\begin{tabular}{|l|l|l|l|l|c|}
\hline $\begin{array}{c}\text { Source of } \\
\text { Variance }\end{array}$ & $\begin{array}{c}\text { Sum of squares } \\
\text { (SS) }\end{array}$ & $\begin{array}{c}\text { Degree of Freedom } \\
\text { (df) }\end{array}$ & $\begin{array}{c}\text { Mean Square } \\
\text { (Ms) }\end{array}$ & F & $\begin{array}{c}\text { Significance of } \\
\text { F }\end{array}$ \\
\hline Between groups & 979.7 & 2 & 1964.14 & 9.32 & .002 \\
\hline Within groups & 984.4 & 13 & 2740.6 & & \\
\hline
\end{tabular}

The result shows that calculated F-value as 9.32 while the critical value at 2 and 13 degree of freedom at 0.05 level of significance was 4.60. This shows that the calculated F-value of 9.32 is greater than the critical value of 4.60. Since the calculated F-value is greater than the critical F-value, the null hypothesis $\left(\mathrm{H}_{0}\right)$ which states that there is no significant variation in type of informal businesses and employment generation in the study area is rejected. Since the null hypothesis is rejected, the alternative hypothesis $\left(\mathrm{H}_{1}\right)$ which states that there is significant variation in the type of informal businesses and employment generation by the informal businesses was accepted.

This result established that a variation exists in employment generation among the informal businesses in the study area.

The second hypothesis which stated that employment generation by informal businesses is not predicted by any variable was tested using one-way analysis of variance (ANOVA) and Multiple Regression analysis. The result is as presented in table 6 below:

The variables considered in the study included; type of business $\left(\mathrm{x}_{1}\right)$, size of business $\left(\mathrm{x}_{2}\right)$, source of income $\left(\mathrm{x}_{3}\right)$, capital outlay $\left(\mathrm{x}_{4}\right)$, services rendered $\left(\mathrm{x}_{5}\right)$, skills (labour) require $\left(\mathrm{x}_{6}\right)$, income generation $\left(\mathrm{x}_{7}\right)$, management type $\left(\mathrm{x}_{8}\right)$ socio-cultural relevance $\left(\mathrm{x}_{9}\right)$ and government policy $\left(\mathrm{x}_{10}\right)$.

Table 6: Analysis of Variance showing the Predictors of Employment Generation by Informal Businesses (a)

\begin{tabular}{|l|l|}
\hline Multiple R & .736 \\
\hline $\mathrm{R}^{2}$ & .696 \\
\hline Standard error & .35972 \\
\hline
\end{tabular}
(b)

\begin{tabular}{|l|l|l|l|l|l|}
\hline \multicolumn{1}{|c|}{ Source of Variation } & \multicolumn{1}{c|}{ SS } & \multicolumn{1}{c|}{ Df } & \multicolumn{1}{c|}{ Ms } & \multicolumn{1}{c|}{ F } & Sig. \\
\hline Regression & 124.956 & 16 & 20.310 & 301.077 & .000 \\
\hline Residual & 42.380 & 1050 & 0.067 & & \\
\hline Total & $\mathbf{1 6 7 . 3 3 6}$ & $\mathbf{1 0 6 6}$ & & & \\
\hline
\end{tabular}

The result in table 6(b) shows an F-ratio of 301.077, a correlation coefficient (R) of 0.73 and a coefficient of determination of 0.696. The F-ratio of 301.077 is greater than the critical value of 23.172. The null hypothesis $\left(\mathrm{H}_{0}\right)$ was therefore rejected and the alternative hypothesis $\left(\mathrm{H}_{1}\right)$ which stated that employment generation by informal businesses is predicted by some variables was accepted.

However, to determine the contribution of each variable to the variation in employment generation, the multiple regression stepwise delete model was applied using SPSS application.

When all the variables were introduced into the equation, only one variable (type of business) met the requirement for inclusion in the equation. Type of business t-score was 0.000 with a coefficient determination of 0.696 meaning that $69.6 \%$ variation in employment generation is explained by the type of informal business.

In the second step, the two variables that satisfied the requirement for inclusion in the equation were size and source of income of businesses. The two variables accounted for $69.7 \%$ variation in employment generation.

The variables that met the requirement for inclusion in the equation in the third step were income generation, 
capital outlay and type of services provided by the informal businesses. The variables explained $65.2 \%$ of variation in employment generation.

In the fourth step of the equation, the variables that qualified for inclusion in the equation were skills required and type of management. These accounted for $63.5 \%$ variation in employment generation.

This result shows that the variables that predict employment generation by informal businesses are type of business, size of business income generation, initial capital outlay, type of services provided, require skill/labour, and type of management.

\section{Discussion of Result}

The finding of the study showed that informal businesses in the study have the following characteristics which affect employment generation:

i) Businesses are majorly owned by sole proprietors.

ii) The major source of financing among the businesses in personal savings.

iii) Low income generation among the businesses. About $62 \%$ businesses generate average daily income of less than $\mathrm{N} 2,000.00$

iv) Unskilled labour constitutes the major source of labour for the businesses.

These characteristics of the businesses have some implications on employment generation in the study area. The implications are as follows.

The dominance of personal savings as a source of financing business would likely limit the growth of businesses. Personal savings may not give the business owners opportunities to expand. It is only when businesses expand that more employment would be created. The utilization of loans and grants creates opportunities for business owners to expand businesses and increase employment creation. Unfortunately, loans and grants accounted for only $4 \%$ of sources of financing of informal businesses in the study area.

The low income generation of informal businesses in the study area is a constraint to employment generation. About $62 \%$ of the business generate average daily income of less than N2,000. The ability of such businesses to expand and generate more employment will be slim. High income generating businesses have higher potential of creating more employment. Higher income generation among businesses would improve the employment generation of the informal businesses (Enobong \& Uduak, 2015).

Another finding of the study is that unskilled labour is the most demanded in the informal businesses. This is because the cost of skilled labour is very high and the informal businesses cannot afford to pay. It is however noted that most of the informal businesses have not embraced modern technology which utilize skilled manpower (Ibiang, 1991). Businesses like printing/computer services, photography and electrical works which demand skill labour constitute only about $19.25 \%$ of the informal business in the study area. The demand for skilled labour among the businesses is therefore very low. This situation is worrisome when the fact that this study established that a variation exist in employment generation among the informal businesses. It is therefore follows that the adoption of modern technology of informal businesses would boast employment generation as skilled and unskilled labour would be demanded. It further follows that strategies that would cause sole proprietors to embrace joint ownership or accept to seek for loans and grants or improve their income generation will improve employment generation of informal businesses in the study area.

This is very pertinent given the fact that the study identified the following, as the predictors of employment generation among informal businesses; type of business, size of business, services provided by the business and income generation. These variables when improved upon will lead to increase in employment generation (Akintoye, 2008 \& Ndem et al 2018).

\section{Summary and Conclusion}

This study aimed at identifying the main predictors of employment generation of informal businesses in Calabar urban. In pursuance of this, two hypotheses were formulated and stated thus; there is no significant variation in the type of informal businesses and employment generation. This was rejected and the second hypothesis stated, in a null $\left(\mathrm{H}_{0}\right)$ as; employment generation by informal businesses is not predicted by any variable was accepted. A one-way Analysis of Variance (ANOVA) was used in testing the hypotheses. The contributions of the variables to the variation were identified using multiple-regression analysis stepwise delete model.

The result established a variation in employment generation among the informal businesses. The main predictors of employment generation among the inform business were identified as; type of business, income generation, nature of services provided and size of business and type of management.

These findings further highlighted the characteristics of informal businesses to include the dominant business ownership by sole proprietors, low income generation, poor sources of financing and utilization of unskilled labour.

These characteristics of informal businesses when considered along side with the predictors of employment generation implies that the poor characteristics of the businesses would constrain high employment generation among businesses in the study area. It therefore follows that an improvement in the following characteristics of 
the informal businesses, type of business ownership, income generation, sources of financing and skill/technology utilization will improve employment generation.

\section{Conclusion}

It generally concluded that since variation exist in employment generation among the informal businesses, it follow that any positive improvement in the variables which affect employment creation will lead to increase in employment generation in the study area.

\section{Recommendation}

In view of the findings, the following are recommended;

1) The operators of small scale businesses should be encouraged to constitute themselves into joint ventures or cooperative societies to enable them attract funding from government and financial institutions.

2) Advocacy campaign and education should be carried out on strategies for expanding and sources for funding of informal businesses.

3) Funding Agencies should as a matter of policy, liberalize the processes of granting loans and grants to small scale Entrepreneurs. Improve incentives should be created for informal businesses with high employment generative capacity. Government policies on tax exemption, supply of inputs like tools and equipment will go a long way to strengthen informal businesses.

4) Further studies should be conducted on employment generative capacity of informal businesses. This will provide a basis for better policy formulation that will consolidate the gains of establishing informal businesses.

\section{REFERENCES}

Adedokun, O. S. (1989) Analysis of Employment situation in small scale industries. A case study of Bakery Industry in Jos. Department of Geography. Lecture series. University of Jos, Nigeria.

Akintoye, I. R. (2008) Reducing Unemployment through Informal Sector: A case study of Nigeria. European Journal of Economics, Finance and Administrative Science. 11:97-106.

Callaway, A. G. (1969) Creating Employment for African Youths. In Yesufu, T. M. (ed) Manpower Problems and Economic Development in Nigeria, Ibadan: O.U.F.

Cross River State Government (CRSG) (2004), Annual Report of Ministry of Commerce \& Industry, Calabar.

Enobong, U. \& Uduak, E. (2015) Employment Generation for small Economy. The Nigerian Case. International Journal of Interdisciplinary Studies (IJIMS) 2(10): 93-103.

Ibiang, E. I. (1991) Employment Generative Capacity of Small Scale businesses in Jos, Plateau State. unpublished M.Sc. Dissertation, Dept of Geography and Planning, University of Jos, Nigeria.

International Labur Organisation (ILO) (1969). Employment, Income and Equality. A strategy for Increasing Productive Employment in Kenya. ILO Geneva.

Ndebbio, J.E.U. (1987) Employment Generative and size of Industries in Nigeria. the case of Cross River State. Economic and Social Studies. 29(2): 149-169.

Ndem, B. E., Effiong, C. E. \& Obot, I. S. (2018) Impact of Entrepreneurial Development on Employment creation in Cross River State. A case of the National Directorate of Employment. International Journal of Academic Research in Economics and Management Science 7(4): 89-102.

Obeleagu-Nzelibe, C. G. (1990) Management of Small Scale Businesses in Nigeria. fourth Dimension Limited, Enugu.

Ofoegbu, O. E. (2010) Productive Employment Generation in Transition Economy. A Nigerian Perspective. Journal of Emerging Trend in Economics and Management Services 1(2): 121-127.

Oluseye, S. A. Ikhide, S \& Akotey, 10(2017) MSMES \& Employment Generation in Nigeria. journal of Developing Areas 51(3): 229-249.

Omolayole, A. (1984), The Private Sector: A paper presented at Nigerian Institute of Management Workshop held in Lagos on the role of Private Sector in Nigerian Economy, Lagos.

Omotosho, W. A. (2015) Employment Generation and National Development in Nigeria. Journal of Economic History 13:13-14.

Onokerhoraye, A. G. \& Omuta, G.E.D. (1996). Urban System and Planning. Geography and Planning Series of Study Notes. Eguavon Printers. Benin City.

Onyemaechi, J. (2013) Role of the Informal Sector in Development of the Nigeria Economy Output and Employment Approach. Journal of Economics \& Development Studies 1(1): 60-74.

Oshagbami, T. A. (1983) Small Scale Business Management in Nigeria. Lagos. Longman.

Valle, F. (2012) Explaining Opportunities and Constraints for Young Agro Entrepreneurs in Africa. Food and Agricultural Organistion (F.A.O), Italy. 